\title{
Dragonfly Support Vector Machine Modelling of the Adsorption Phenomenon of Certain Phenols by Activated Carbon Fibres
}

\author{
M. Hentabli, ${ }^{a^{*}}$ A. -E. Belhadj, and F. Dahmoune b,c \\ a Laboratory of Biomaterials and Transport Phenomena (LBMPT), Faculty of Technology, \\ University Yahia Fares of Médéa 26 000, Médéa, Algeria

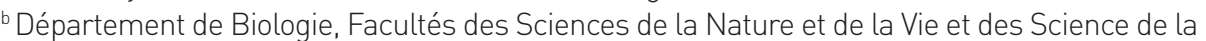 \\ Terre, Université de Bouira, 10000 Bouira, Algeria \\ 'Laboratoire de Biomathématique, Biophysique, Biochimie, et Scientométrie (L3BS), Faculté \\ des Sciences de la Nature et de la Vie, Université de Bejaia, 06000 Bejaia, Algeria
}

https://doi.org/10.15255/KUI.2020.073

KUI-35/2021

Original scientific paper

Received November 10, 2020

Accepted February 24, 2021

\begin{abstract}
The objective of this research was to build a mathematical model based on a Support Vector Machine (SVM) capable of predicting the amount adsorbed at equilibrium $\left(q_{\mathrm{e}}\right)$. Activated carbon fibres (ACF) were used for the adsorption of certain phenols (phenol, 2-chlorophenol, 4-chlorophenol, 2,4,6-trichlorophenol, 4-nitrophenol, and 2,4-dinitrophenol). An experimental dataset of 129 points was collected from previously published papers. The inputs considered for modelling were temperature ( $T)$, concentration at equilibrium $\left(C_{\mathrm{e}}\right)$, and two descriptors (boiling point $(B P)$ and density $(d)$ ) to differentiate between the pollutants studied. The data used were pre-processed by the statistical analysis to ensure that they were adequate for modelling. The results showed a superiority of the Gaussian kernel function DA-SVM model demonstrated by its determination coefficient $\left(R^{2}=0.997\right)$ and root mean squared error $\left(\mathrm{RMSE}=0.027 \mathrm{mmoll}^{-1}\right)$.
\end{abstract}

\section{Keywords}

Adsorption, phenols, support vector machine, dragonfly algorithm, activated carbon fibre, amount adsorbed at equilibrium

\section{Introduction}

Water pollution is an alteration in its quality and nature that makes its use dangerous and/or disrupts the aquatic ecosystem. It concerns surface water (rivers, bodies of water) and/or groundwater. Its main origins are human activity, industries, agriculture, and domestic and industrial waste landfills. ${ }^{1-3}$ Phenol and its derivatives are used in a number of applications such as the chemical, pharmaceutical, petroleum, paper, wood, rubber, dyes, and pesticide industries. Phenols are classified as priority pollutants because of their toxicity to organisms, even at low concentrations. ${ }^{4,5}$ Their adverse effects on the environment and public health have been demonstrated by growing evidence, such as the death of aquatic life, inhibition of normal activities of the microbial community, and carcinogenicity in animals. ${ }^{6}$ Due to the high toxicity, high prevalence and poor biodegradability of phenols, it is necessary to remove them from wastewater before discharging them into water bodies.

The adsorption treatment process is one of the most important technologies today. It is widely used for pollution control and purification in a wide variety of fields, for example, the petroleum, petrochemical and chemical industries, environmental, and pharmaceutical applications. ${ }^{7,8}$

Activated carbon fibres (ACF) are generally microporous, with a large surface area and a narrow pore distribution. The microporous nature gives ACFs adsorption advantages because the adsorption energy is increased in small pores.

${ }^{*}$ Corresponding author: Mohamed Hentabli, PhD student Email: hentm92@hotmail.fr
In addition, ACFs have a large external surface area and their micropores are directly exposed to the surface, resulting in a rapid rate of adsorption. ${ }^{9}$

Machine learning (ML) is a type of artificial intelligence (AI) that allows software applications to be more precise in predicting outcomes without being explicitly programmed to do so. ${ }^{10-15}$

Support Vector Machine (SVM) is a machine learning or statistical technique defined for the prediction of variables. Generally, this technique is employed to avoid the overfitting and convex optimisation problems (no local minima), and it runs well on smaller databases. This research consists of studying the data of the adsorption of phenols with ACFs, and of modelling by the machine learning technique (DA-SVM).

\section{Support vector machines (SVM) technique}

The SVM is based on a statistical learning theory. This method was introduced by Vapnik. ${ }^{16-18}$ The architecture of SVM model is not determined a priori. The mathematical expression of the output estimation of the SVM is given as follows:

$$
f(x)=w \cdot \varnothing(x)+b
$$

where $w$ is a weight vector, $b$ is a bias, denotes the dot product, and $\varnothing$ is the non-linear transfer function that maps 
the input vectors into a high-dimensional feature space, in which theoretically a simple linear regression can cope with the complex non-linear regression of the input space. Vapnik introduced the following convex optimisation problem with a $\varepsilon$-insensitivity loss function to obtain the solution to Eqs. (2) and (3): $:^{19}$

$$
\operatorname{minimize}: \frac{1}{2} w^{2}+C \sum_{K=1}^{N}\left(\xi_{k}^{+}+\xi_{k}^{-}\right)
$$

subject to $\left\{\begin{array}{c}y_{k}-\left(w \cdot \varnothing\left(x_{k}\right)+b\right) \leq \varepsilon+\xi_{k}^{+} \\ -y_{k}+\left(w \cdot \varnothing\left(x_{k}\right)+b\right) \leq \varepsilon+\xi_{k}^{-} \quad k=1,2, \ldots \ldots, N \\ \xi_{k}^{+}, \xi_{k}^{-} \geq 0\end{array}\right.$

where $\xi_{k}^{+}$and $\xi_{k}^{-}$are slack variables that penalize training errors by the loss function over the error tolerance $\varepsilon$, and $C$ is a positive trade-off parameter or capacity parameter that determines the degree of the empirical error in the optimisation problem and determines the trade-off between the flatness of the function and the amount to which deviations larger than $(\varepsilon)$ are tolerated.

Eqs. (4) and (5) can be solved using the Lagrangian multipliers and the Karush-Kuhn-Tucker (KKT) optimality conditions, as follows: ${ }^{20}$

$$
f\left(x, \alpha_{i}, \alpha_{i}^{*}\right)=\sum_{i=1}^{N}\left(\alpha_{i}-\alpha_{i}^{*}\right) \cdot K\left(x, x_{i}\right)+b
$$

where $\alpha_{\mathrm{i}}$ and $\alpha_{\mathrm{i}}^{*}$ are the Lagrangian multipliers, $K$ is a kernel function defined by an inner product of the nonlinear transfer functions: ${ }^{19}$

$$
K\left(x, x_{i}\right)=\exp \left(-\frac{x-x_{i}^{2}}{\sigma^{2}}\right)
$$

\section{SVM optimisation with Dragonfly algorithm (DA) technique}

The chosen methodology can be schematised in accordance with the flowchart in Fig. 1, which includes the following steps:

The program shown in Fig. 1 depends on the technical SVM and the method of optimisation by the Dragonfly algorithm (DA) proposed by S. Mirjalili. ${ }^{21}$ The DA initially feeds the SVM with a random combination of hyperplane parameters in their previously defined ranges. In five iterations, the steps starting with the data division and up to the development of the SVM model are repeated, and the minimum value of RMSE obtained is saved as the best value..$^{23-26}$

The DA then generates a new population of parameter hyperplanes for the SVM algorithm, and the same set of steps is repeated in order to obtain a new best RMSE, among which the minimum RMSE corresponds to the DA-SVM model optimal result.

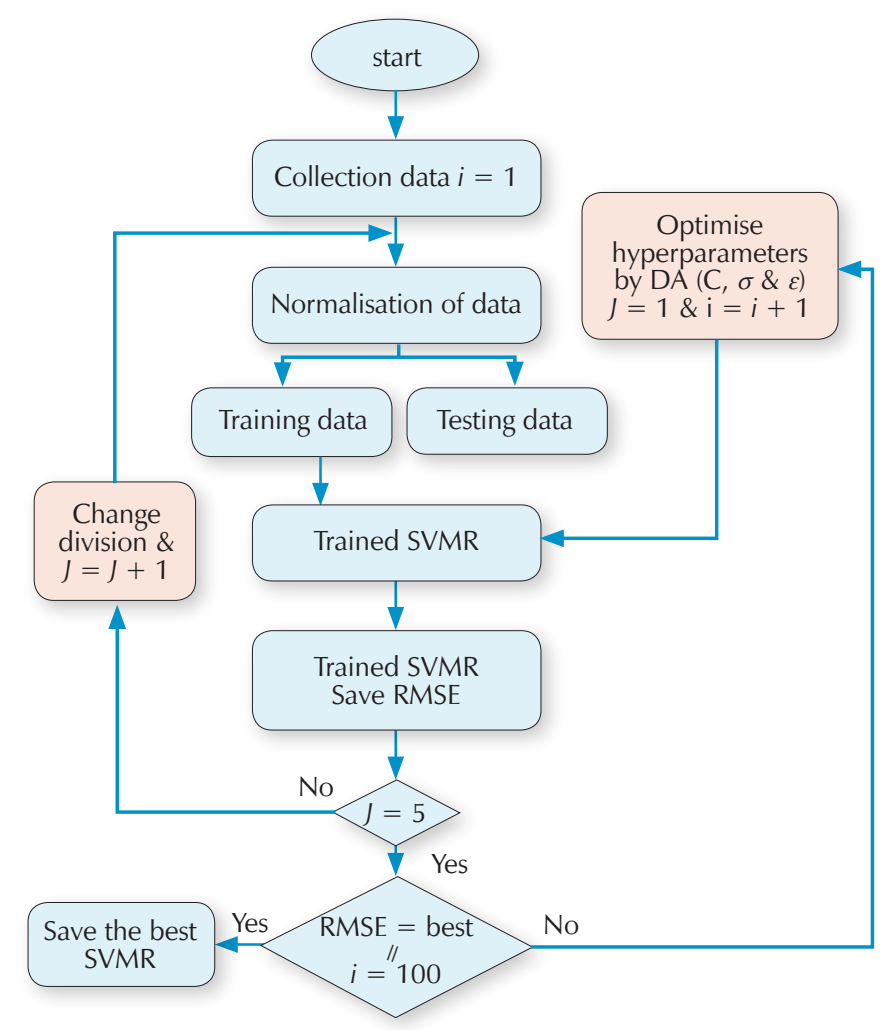

Fig. 1 - DA-SVM technique ${ }^{12}$

Numeric values in the input data matrix have been normalised to improve the optimisation and speed convergence. The normalisation function is expressed by the following Eq. (6)

$$
X_{n}=X^{0.09}
$$

To assess the predictive power of the DA-SVM model, a root mean squared error (RMSE) Eq. (7) and coefficient of determination $\left(R^{2}\right)$ ) Eq. (8) were used as evaluation criteria.

$$
\begin{gathered}
\text { RMSE }=\sqrt{\frac{\sum_{i=1}^{n}\left(q_{\mathrm{ei}}^{\text {exp }}-q_{\mathrm{e} i}^{\text {cal }}\right)^{2}}{n}} \\
R^{2}=1-\frac{S S_{\text {res }}}{S S_{\text {tot }}}=1-\frac{\sum_{i=1}^{n}\left(q_{\mathrm{e} i}^{\text {exp }}-q_{\mathrm{e} i}^{\text {cal }}\right)^{2}}{\sum_{i=1}^{n}\left(q_{\mathrm{e} i}^{\text {exp }}-q_{\mathrm{e}(\text { moy })}\right)^{2}}
\end{gathered}
$$

\section{Data collection, pre-treatment, and analysis}

The modelling data was collected from the literature, ${ }^{22}$ the database must be analysed statistically. Table 1 summarises the values of some statistical parameters, such as standard deviation, variance, and KURTOSIS. The database contains 21 adsorption systems (seven phenols multiplied by three temperature changes). The amount adsorbed at equilibrium is predicted by the following variables: temperature 
Table 1 - Statistical criteria

\begin{tabular}{c|c|c|c|c|c|c|c}
\hline \multicolumn{2}{|c|}{} & & Unit & Min & Max & STD & KURTOSIS \\
\hline \multirow{4}{*}{ input } & molecular weight & $M_{\mathrm{w}}$ & $\mathrm{g} \mathrm{mol}^{-1}$ & 94.11 & 197.45 & 31.84 & -0.94 \\
\cline { 2 - 8 } & density & $d$ & $\mathrm{~g} \mathrm{~cm}^{-3}$ & 1.07 & 1.68 & 0.20 & -1.00 \\
\cline { 2 - 8 } & boiling point & $B P$ & ${ }^{\circ} \mathrm{C}$ & 113.00 & 279.00 & 47.66 & -0.35 \\
\cline { 2 - 8 } & temperature & $T$ & ${ }^{\circ} \mathrm{C}$ & 25.00 & 55.00 & 12.36 & -1.52 \\
\cline { 2 - 8 } & Concentration at equilibrium & $C_{\mathrm{e}}$ & $\mathrm{mmol} \mathrm{I}^{-1}$ & 0.01 & 1.12 & 0.19 & 3.89 \\
\hline \multirow{2}{*}{ output } & amount adsorbed at equilibrium & $q_{\mathrm{e}}$ & $\mathrm{mmol} \mathrm{g}^{-1}$ & 0.42 & 2.68 & 0.54 & -0.78 \\
\hline
\end{tabular}

and concentration at equilibrium as operating conditions, and molecular weight, density, and boiling point as descriptors to differentiate between the phenols.

Fig. 2 represents the multicollinearity test of the input variables. The test is a plot of the Kendall rank correlation coefficients between all pairs of variables, indicating a hypothesis test to determine which correlations are significantly different from zero.

\section{Results and discussion}

SVM was optimised by the dragonfly method. In a hybrid program called DA-SVM, the iterations were set at 30, and the number of search agents at 10 . The program controls the hyperplane parameters $(C, \varepsilon, \mathrm{n}$, and $\sigma)$, in the domains following $C \in[1 \mathrm{e}-3,1 \mathrm{e} 3], \sigma \in[1 \mathrm{e}-3,1 \mathrm{e} 3], \varepsilon \in[0,1]$, pol- ynomial order « $n »[2,5]$ and the 'Gaussian' (Eq. 9) and 'polynomial' (Eq. 10) kernel functions.

$$
\begin{aligned}
& \text { Gaussian }=\exp \left(-x_{j}-x_{k}^{2}\right) \\
& \text { Polynomial }=\left(1+x_{j}^{\prime} x_{k}\right)^{n}
\end{aligned}
$$

The database was randomly divided by the Holdout Partitions method into two sets: one for the learning (train), and another for validation, consisting of $80 \%$ and $20 \%$, respectively.

\subsection{Polynomial kernel function results}

Fig. 3 displays the linear regression curve of the amount adsorbed at equilibrium $\left(q_{\text {e(cal) }}\right)$ estimated by the DA-SVM optimised with the experimental amount adsorbed at

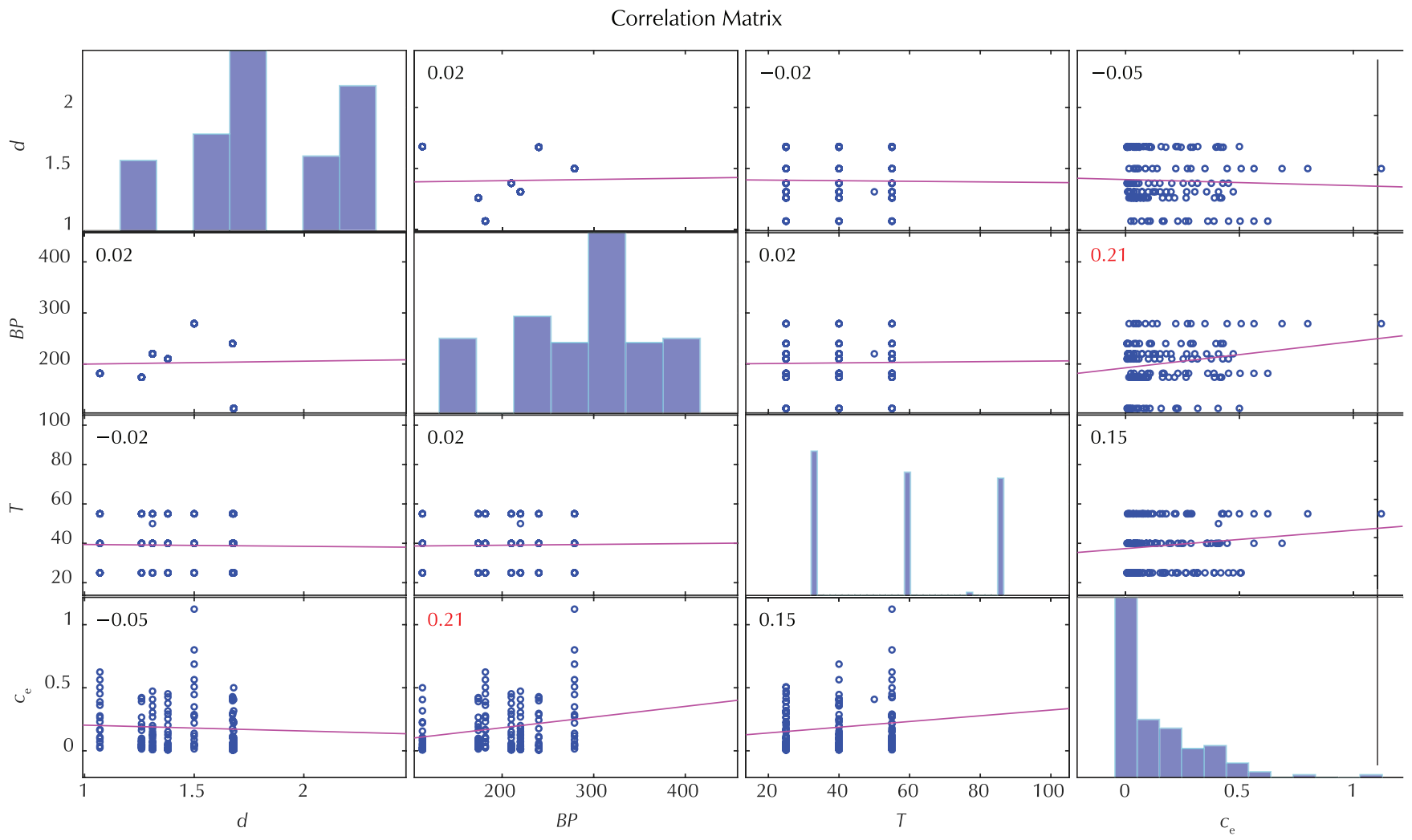

Fig. 2 - Multicollinearity test 
equilibrium $\left(q_{\text {e(exp) }}\right)$ for the two phases: learning (train) and validation, in using the polynomial kernel function with a regression vector $[\alpha$ (slope), $\beta$ (y-intercept), $R$ (correlation coefficient) $]=[0.95,0.015,0.974]$, and Table 4 summarises the parameters of the model.

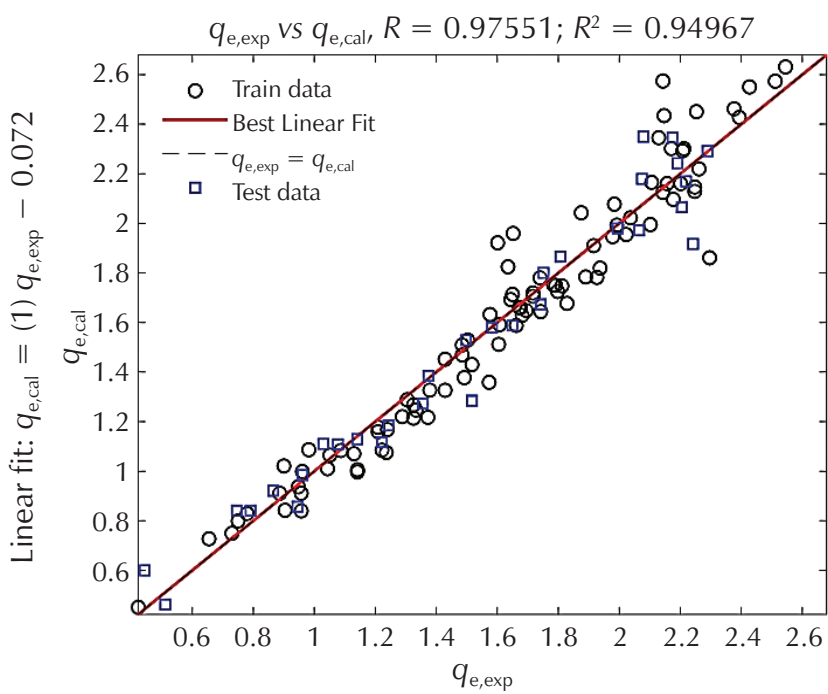

Fig. 3 - Linear regression between the experimental $q_{\mathrm{e}}$ and $q_{\mathrm{e}}$ calculated by the DA-SVM model using the polynomial kernel function

\subsection{Gaussian kernel function results}

The linear regression curve of the $\left(q_{\mathrm{e}}\right)$ calculated by DASVM optimised with the $\left(q_{\mathrm{e}}\right)$ experimental for the two phases (learning and validation) using the Gaussian kernel function is represented in Fig. 5 with a vector regression $[\alpha$ (slope), $\beta$ (y-intercept), $R$ (correlation coefficient) $]=[1.00$, $0.0017,0.998]$, and Table 3 summarises the model parameters.

\subsection{Comparative study of the results of the two approaches}

The performances of the models developed in this work were compared to the statistical criterion (Eqs. 7 and 8).

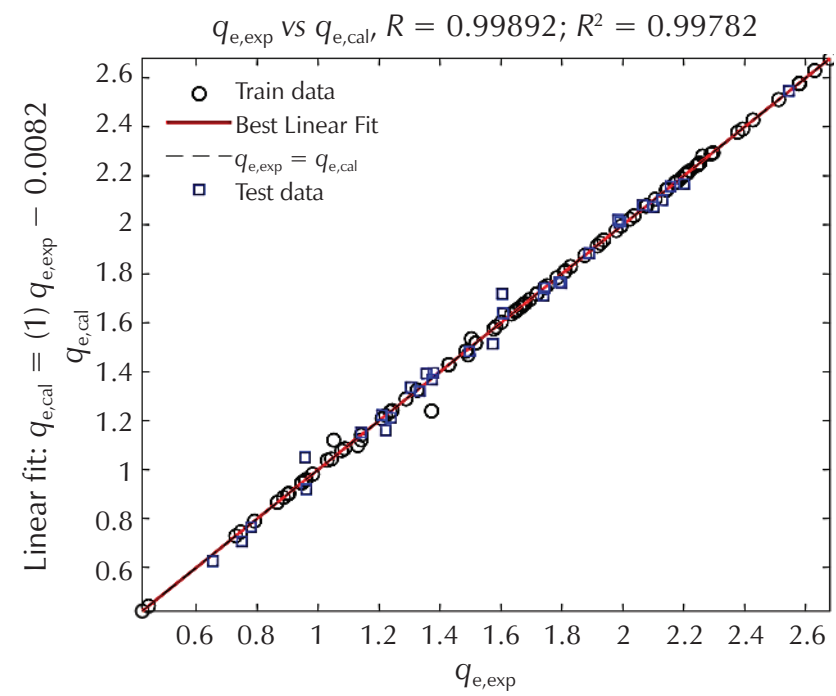

Fig. 4 - Linear regression between the experimental $q_{\mathrm{e}}$ and $q_{\mathrm{e}}$ calculated by the DA-SVM model using the Gaussian kernel function

To this end, two approaches, among which a polynomial kernel function DA-SVM model and a Gaussian kernel function DA-SVM model, were evaluated in terms of correlation performance and prediction accuracy (Fig. 5).

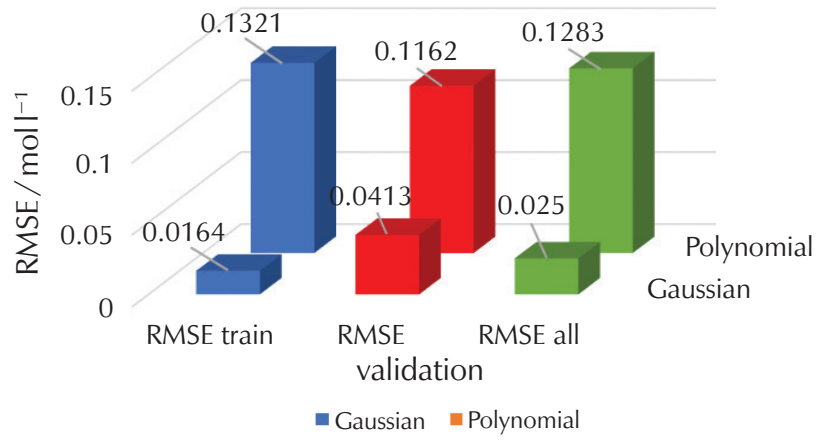

Fig. 5 - Comparison of the Gaussian kernel function DA-SVM model and polynomial kernel function DA-SVM model

Table 2 - Model parameters (Polynomial kernel function)

\begin{tabular}{c|c|c|c|c|c|c|c|}
\hline C & $\begin{array}{c}\text { Polynomial } \\
\text { order }\end{array}$ & Epsilon $\varepsilon$ & Function & $\begin{array}{c}\text { Amount of support } \\
\text { vectors }\end{array}$ & $\begin{array}{c}\text { RMSE } \\
\text { learning }\end{array}$ & $\begin{array}{c}\text { RMSE } \\
\text { validation }\end{array}$ & $\begin{array}{c}\text { RMSE } \\
\text { ALL }\end{array}$ \\
\hline 85 & 2 & 0.0015 & Polynomial kernel & 97 & 0.1321 & 0.1162 & 0.1283 \\
\hline
\end{tabular}

Table 3 - Model parameters (Gaussian kernel function)

\begin{tabular}{c|c|c|c|c|c|c|c}
\hline$C$ & Sigma $\sigma$ & Epsilon $\varepsilon$ & Function & $\begin{array}{c}\text { Amount of support } \\
\text { vectors }\end{array}$ & $\begin{array}{c}\text { RMSE } \\
\text { train }\end{array}$ & $\begin{array}{c}\text { RMSE } \\
\text { validation }\end{array}$ & $\begin{array}{c}\text { RMSE } \\
\text { ALL }\end{array}$ \\
\hline 44 & 1.75 & $4.15 \cdot 10^{-04}$ & Gaussian kernel & 92 & 0.0164 & 0.0413 & 0.0250 \\
\hline
\end{tabular}


For more details, it was noticed that the error of learning Gaussian kernel function DA-SVM model is eight times less than the error of learning polynomial kernel function DASVM model, and the Gaussian kernel function DA-SVM model test error three times less than the polynomial kernel function DA-SVM model test error. In general, it can be concluded that the prediction capacity of Gaussian kernel function DA-SVM model is five times better than the prediction capacity of polynomial kernel function DA-SVM model.

\subsection{Graphical representation of the Gaussian kernel function DA-SVM model}

Figs. 6-12 represent the adsorption kinetics of certain substituted phenols (phenol, 2-chlorophenol '2-CP', 4-chlorophenol '4-CP', 2,4,6-trichlorophenol '2,4,6 TCP', 4-nitrophenol '4-NP', and 2,4-dinitrophenol '2,4DNP') experimental and calculated by optimal Gaussian kernel function DA-SVM model.

Fig. 6 shows a projection of the experimental values of the phenol adsorption at 25,40 , and $55^{\circ} \mathrm{C}$ by ACFs on the predicted values by the Gaussian kernel function DA-SVM

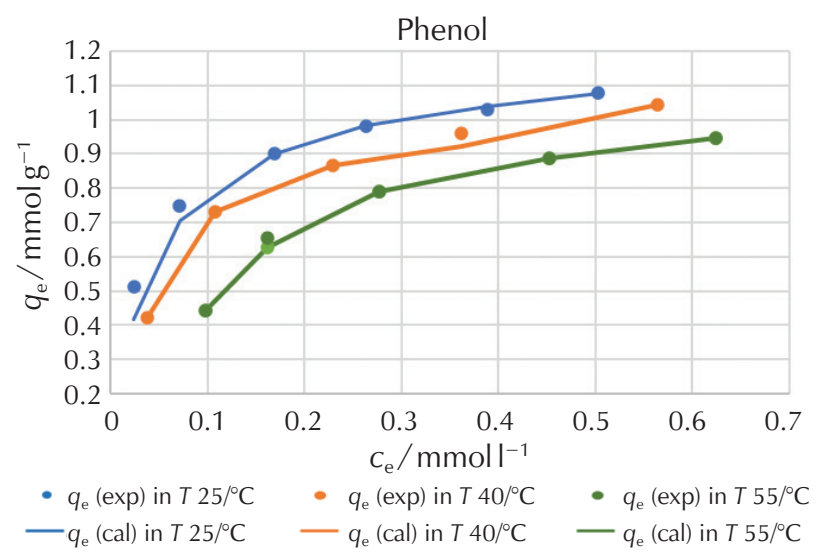

Fig. 6 - Phenol adsorption kinetics by ACF at different temperatures $\left(25,40\right.$, and $\left.55^{\circ} \mathrm{C}\right)$.

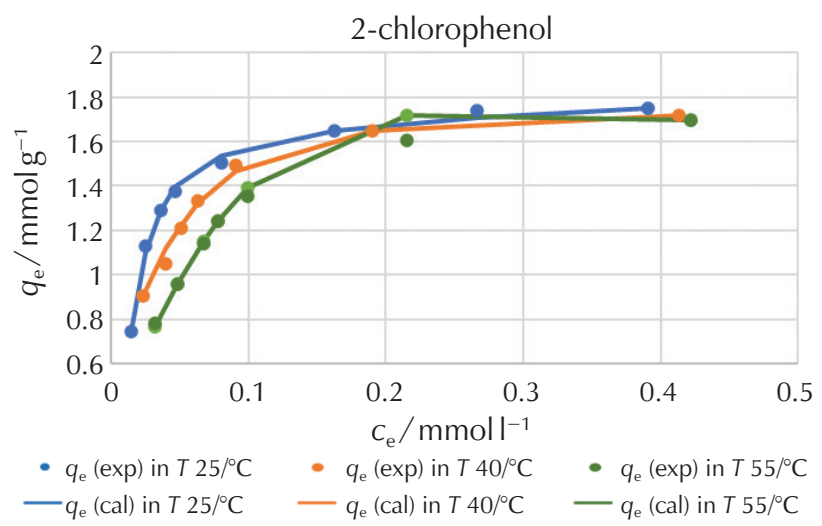

Fig. 7 - 2-chlorophenol adsorption kinetics by ACF at different temperatures $\left(25,40\right.$, and $\left.55^{\circ} \mathrm{C}\right)$ model. The results indicate the ability of the model to predict with high accuracy.

Fig. 7 proves the large amplitude of the Gaussian kernel function DA-SVM model for the prediction of the amount adsorbed at equilibrium of 2-chlorophenol at temperatures $25,40,55^{\circ} \mathrm{C}$.

Results in Fig. 8 indicate the ability of the model to predict with high accuracy. In addition, the projection of the experimental values of the 4-chlorophenol adsorption at 25,40 , and $55{ }^{\circ} \mathrm{C}$ by ACFs on the predicted values by the Gaussian kernel function DA-SVM model was perfect.

The experimental data of 2,4-dichlorophenol adsorbed amount at equilibrium at 25,40 , and $55^{\circ} \mathrm{C}$, and the data calculated by the Gaussian kernel function DA-SVM model are shown in Fig. 9. It can be observed that the model has excellent prediction.

Projecting experimental values of 2,4,6-trichlorophenol adsorbed at 25,40 , and $55^{\circ} \mathrm{C}$ by ACFs over the values predicted by a Gaussian kernel function DA-SVM model demonstrates the model's ability to predict with high accuracy (Fig. 10).

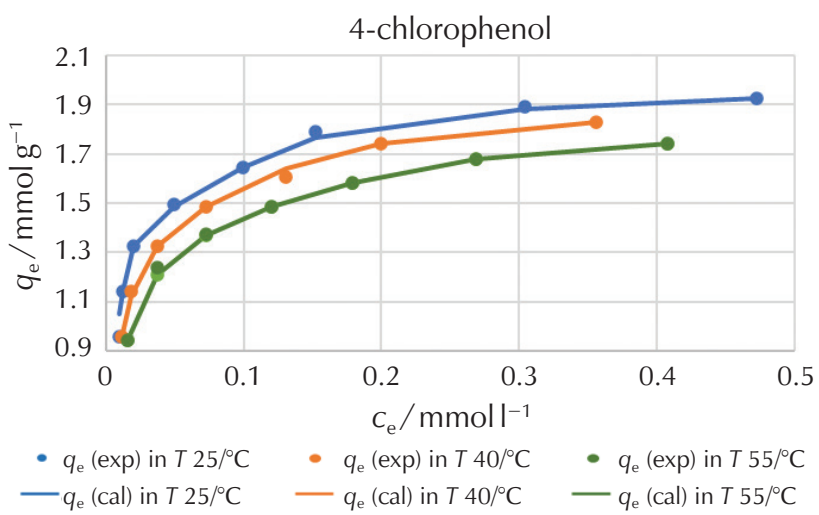

Fig. 8 - 4-chlorophenol adsorption kinetics by ACF at different temperatures $\left(25,40\right.$, and $\left.55^{\circ} \mathrm{C}\right)$

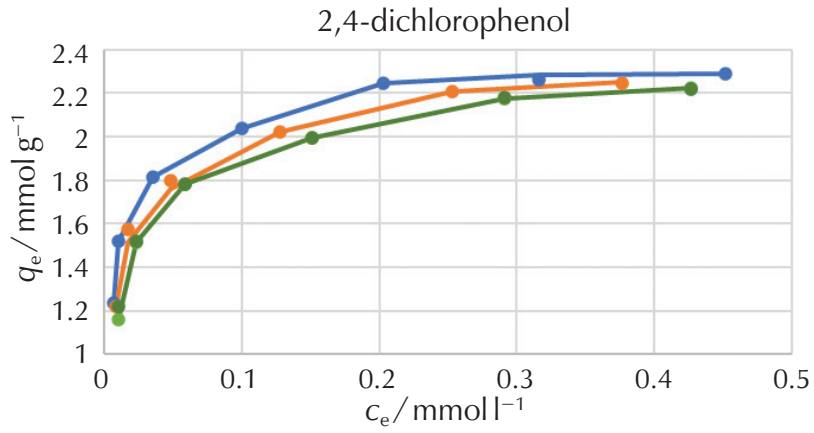

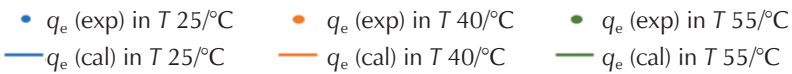

Fig. 9 -2,4-dichlorophenol adsorption kinetics by ACF at different temperatures $\left(25,40\right.$, and $\left.55^{\circ} \mathrm{C}\right)$ 


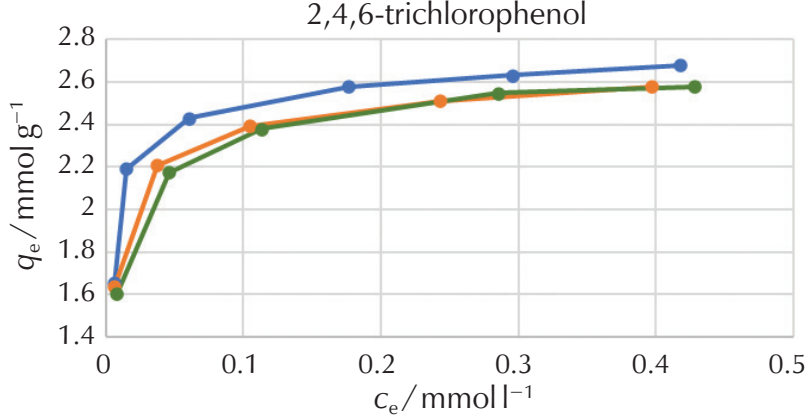

- $\mathrm{q}_{\mathrm{e}}(\exp )$ in $T 25 /{ }^{\circ} \mathrm{C} \quad-\mathrm{q}_{\mathrm{e}}(\exp )$ in $T 40 /{ }^{\circ} \mathrm{C} \quad-\mathrm{q}_{\mathrm{e}}(\exp )$ in $T 55 /{ }^{\circ} \mathrm{C}$ $-q_{\mathrm{e}}$ (cal) in $T 25 /{ }^{\circ} \mathrm{C}-q_{\mathrm{e}}$ (cal) in $T 40 /{ }^{\circ} \mathrm{C}-q_{\mathrm{e}}$ (cal) in $T 55 /{ }^{\circ} \mathrm{C}$

Fig. 10 - 2,4,6-trichlorophenol adsorption kinetics by ACF at different temperatures $\left(25,40\right.$, and $\left.55^{\circ} \mathrm{C}\right)$

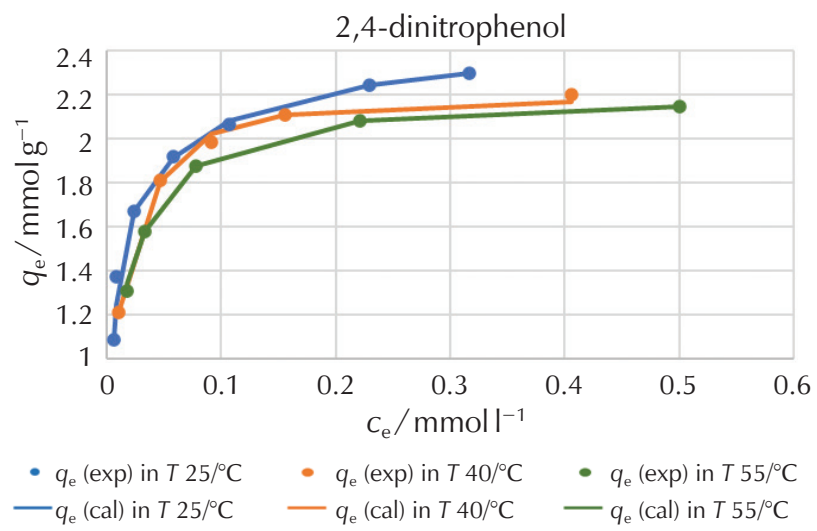

Fig. 12 - 2,4-dinitrophenol adsorption kinetics by ACF at different temperatures $\left(25,40\right.$, and $\left.55^{\circ} \mathrm{C}\right)$

The Gaussian kernel function DA-SVM model demonstrated its great ability to predict the amount adsorbed at equilibrium of 4-nitrophenol at 25,40 , and $55^{\circ} \mathrm{C}$, as shown in Fig. 11.

The results (Fig. 12) indicate the ability of the Gaussian kernel function DA-SVM model to predict with high accuracy the values of adsorption of 2,4-dinitrophenol at 25, 40, and $55{ }^{\circ} \mathrm{C}$ by ACFs.

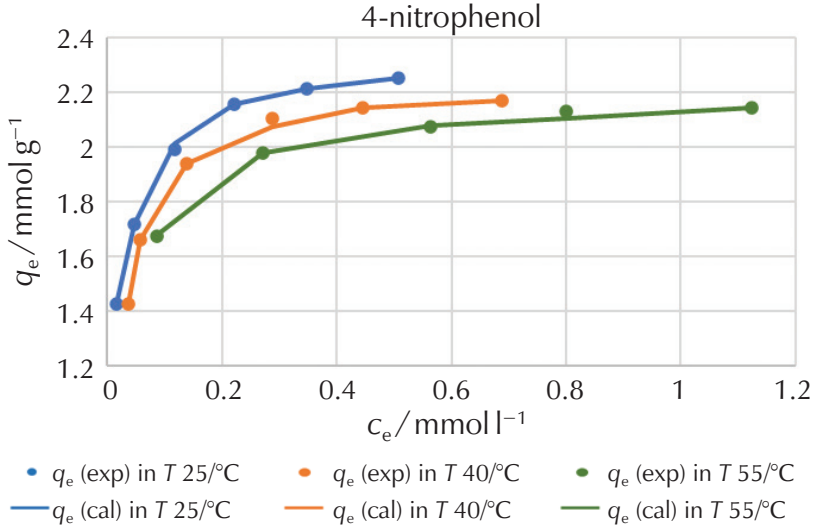

Fig. 11 - 4-nitrophenol adsorption kinetics by ACF at different temperatures $\left(25,40\right.$, and $\left.55^{\circ} \mathrm{C}\right)$

From the results of $R^{2}$ and RMSE of 21 systems mentioned in Table 4, it was observed that Gaussian kernel function DA-SVM model had a great capacity to predict the values related to the amount adsorbed at equilibrium with a confined RMSE error between [0.014-0.051]/mmol I-1 and adjustment capacities $R^{2}$ between [0.991-1.000].

\section{Conclusion}

In this research, a Dragonfly Algorithm-based Support Vector Machine (DA-SVM) mathematical model was constructed to predict the amount adsorbed at equilibrium of phenol, 2-chlorophenol, 4-chlorophenol, 2,4,6-trichlorophenol, 4-nitrophenol, and 2,4-dinitrophenol by the ACFs at three temperature levels $\left(25,40\right.$, and $\left.55^{\circ} \mathrm{C}\right)$.

The amount adsorbed at equilibrium $\left(q_{\mathrm{e}}\right)$ was studied with a database containing the experimental conditions (temperature $(T)$ and concentration at equilibrium $\left.\left(C_{\mathrm{e}}\right)\right)$, and three descriptors to distinguish phenols (molecular weight $\left(M_{\mathrm{w}}\right)$, density $(d)$, and boiling point $(B P)$ to differentiate the phenols. The inputs and output were statistically studied, and the analysis results proved their ability to predict with no multicollinearity.

Table 4 - Statistical criteria modelling by Gaussian kernel function DA-SVM model

\begin{tabular}{|c|c|c|c|c|c|c|c|c|c|c|c|c|c|c|c|c|c|c|c|c|c|}
\hline & \multicolumn{3}{|c|}{ Phenol } & \multicolumn{3}{|c|}{ 2-CP } & \multicolumn{3}{|c|}{ 4-CP } & \multicolumn{3}{|c|}{ 2,4-DCP } & \multicolumn{3}{|c|}{ 2,4,6-ТCP } & \multicolumn{3}{|c|}{ 4-NP } & \multicolumn{3}{|c|}{ 2.4-DNP } \\
\hline $\mathrm{T} /{ }^{\circ} \mathrm{C}$ & 25 & 40 & 55 & 25 & 40 & 55 & 25 & 40 & 55 & 25 & 40 & 55 & 25 & 40 & 55 & 25 & 40 & 55 & 25 & 40 & 55 \\
\hline$R^{2}$ & $\begin{array}{l}\infty \\
\stackrel{2}{\sigma} \\
0\end{array}$ & $\begin{array}{l}n \\
\sigma \\
\sigma \\
0\end{array}$ & बे & $\begin{array}{l}\stackrel{0}{0} \\
\stackrel{2}{0}\end{array}$ & $\begin{array}{l}\bar{S} \\
\text { S. }\end{array}$ & $\begin{array}{l}8 \\
\circ \\
\circ\end{array}$ & 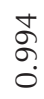 & $\begin{array}{l}\stackrel{0}{\circ} \\
\stackrel{\sigma}{0} \\
0\end{array}$ & $\begin{array}{l}\stackrel{\sigma}{\circ} \\
\stackrel{0}{0}\end{array}$ & $\underset{\sim}{\stackrel{8}{8}}$ & $\begin{array}{l}\hat{\sigma} \\
\text { Oे } \\
\text { o. }\end{array}$ & \begin{tabular}{l}
$\infty$ \\
\multirow{\sigma}{\circ}{} \\
0
\end{tabular} & $\underset{\sim}{\&}$ & $\underset{\sim}{\stackrel{8}{8}}$ & $\underset{\sim}{\stackrel{8}{\&}}$ & $\begin{array}{l}\stackrel{\sigma}{\circ} \\
\stackrel{0}{0}\end{array}$ & $\begin{array}{l}\mathscr{\sigma} \\
\sigma \\
0\end{array}$ & $\begin{array}{l}0 \\
\stackrel{2}{0} \\
0\end{array}$ & $\begin{array}{l}\bar{\sigma} \\
\text { o. }\end{array}$ & $\begin{array}{l}\circ \\
\stackrel{2}{0} \\
0\end{array}$ & $\begin{array}{l}0 \\
\stackrel{2}{0} \\
0\end{array}$ \\
\hline 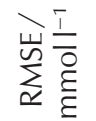 & 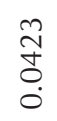 & $\begin{array}{l}\bar{\infty} \\
\vdots \\
0\end{array}$ & 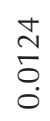 & $\begin{array}{l}\overline{0} \\
0 \\
0 \\
0\end{array}$ & $\begin{array}{l}\hat{N} \\
\stackrel{\infty}{I} \\
0 \\
0 \\
0\end{array}$ & $\begin{array}{l}\hat{N} \\
\text { ڤ̊ } \\
0 \\
0\end{array}$ & \begin{tabular}{l}
$\bar{f}$ \\
\multirow{2}{*}{} \\
0 \\
0
\end{tabular} & $\begin{array}{l}\infty \\
\stackrel{\infty}{0} \\
\vdots \\
0\end{array}$ & $\begin{array}{l}0 \\
0 \\
0 \\
0\end{array}$ & $\begin{array}{l}\stackrel{n}{\Omega} \\
\stackrel{8}{8} \\
0\end{array}$ & $\begin{array}{l}\bar{\infty} \\
\stackrel{0}{1} \\
0 \\
0\end{array}$ & 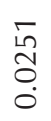 & $\frac{+}{8}$ & 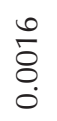 & $\begin{array}{l}+ \\
\\
0\end{array}$ & $\begin{array}{l}8 \\
\& \\
0 \\
0\end{array}$ & \begin{tabular}{l}
0 \\
\multirow{2}{*}{} \\
0 \\
0
\end{tabular} & $\stackrel{\stackrel{n}{N}}{\stackrel{0}{0}}$ & $\begin{array}{l}\text { J } \\
\stackrel{1}{0} \\
0 \\
0\end{array}$ & $\begin{array}{l}\stackrel{\mathscr{N}}{\mathrm{N}} \\
\stackrel{0}{0} \\
0\end{array}$ & $\underset{\dot{J}}{\stackrel{J}{\sigma}}$ \\
\hline
\end{tabular}


The $q_{\mathrm{e}}$ modelled was by the SVM technique, the Dragonfly optimisation algorithm (DA) was used to assist SVM to refine its hyperplane parameters, and Gaussian kernel function and polynomial kernel function were tested. The Gaussian kernel function DA-SVM model showed an advantage by giving more accurate values related to a global determination coefficient $\left(R^{2}=0.997\right)$ and a global root mean squared error $\left(\right.$ RMSE $\left.=0.027 \mathrm{mmoll}^{-1}\right)$.

\section{ACKNOWLEDGEMENTS}

The authors acknowledge the Directorate-General for scientific research and technological development (DGRSDT)-MESRS, Algeria. The authors acknowledge Mr. Houssam Eddine Slama.

\section{Notes}

Authors declare that there is no conflict of interest.

\section{References Literatura}

1. U. Vashkurak, L. Shevchuk, I. Aftanaziv, A. Romaniv, The Influence of Ultrasound Cavitation on the Process of Degradation of Organic Substances in Wastewater of Pharmaceutical Production, Kem. Ind. 69 (11-12) (2020) 631-638, doi: https://doi.org/10.15255/KUI.2020.009.

2. L. Mouni, L. Belkhiri, J.-C. Bollinger, A. Bouzaza, A. Assadi, A. Tirri, F. Dahmoune, K. Madani, H. Remini, Removal of Methylene Blue from Aqueous Solutions by Adsorption on Kaolin: Kinetic and Equilibrium Studies, Appl. Clay Sci. 153 (2018) 38-45, doi: https://doi.org/10.1016/j.clay.2017.11.034.

3. Š. Delibašić, J. Huremović, S. Žero, S. Gojak-Salimović, Water Quality of the Trstionica River (Bosnia and Herzegovina), Kem. Ind. 69 (7-8) (2020) 371-376, doi: https://doi. org/10.15255/KUI.2019.061.

4. N. A. S. Mohammed, R. A. Abu-Zurayk, I. Hamadneh, A. H. Al-Dujaili, Phenol Adsorption on Biochar Prepared from the Pine Fruit Shells: Equilibrium, Kinetic and Thermodynamics Studies, J. Environ. Manag. 226 (2018) 377-385, doi: https://doi.org/10.1016/j.jenvman.2018.08.033.

5. S. F. Lütke, A. V. Igansi, L. Pegoraro, G. L. Dotto, L. A. A. Pinto, T. R. S. Cadaval, Preparation of Activated Carbon from Black Wattle Bark Waste and Its Application for Phenol Adsorption, J. Environ. Chem. Eng. 7 (5) (2019) 103396, doi: https://doi.org/10.1016/j.jece.2019.103396.

6. A. Mandal, S. K. Das, Phenol Adsorption from Wastewater Using Clarified Sludge from Basic Oxygen Furnace, J. Environ. Chem. Eng. 7 (4) (2019) 103259, doi: https://doi. org/10.1016/j.jece.2019.103259.

7. S. Luo, C. Liu, S. Zhou, W. Li, C. Ma, S. Liu, W. Yin, H. J. Heeres, W. Zheng, K. Seshan, S. He, ZnO Nanorod Arrays Assembled on Activated Carbon Fibers for Photocatalytic Degradation: Characteristics and Synergistic Effects, Chemosphere 261 (2020) 127731, doi: https://doi. org/10.1016/j.chemosphere.2020.127731.

8. V. Ocelić Bulatović, L. Štajduhar, S. Majdandžić, K. Karadakić, D. Kučić Grgić, Utjecaj onečišćenja zraka na razvoj astme, Kem. Ind. 69 (1-2) (2020) 17-23, doi: https://doi. org/10.15255/KUI.2019.018.
9. X. Duan, C. Srinivasakannan, X. Wang, F. Wang, X. Liu, Synthesis of Activated Carbon Fibers from Cotton by Microwave Induced $\mathrm{H}_{3} \mathrm{PO}_{4}$ Activation, J. Taiwan Inst. Chem. Eng. 70 (2017) 374-381, doi: https://doi.org/10.1016/j. jtice.2016.10.036.

10. S. Keskes, S. Hanini, M. Hentabli, M. Laidi, Artificial Intelligence and Mathematical Modelling of the Drying Kinetics of Pharmaceutical Powders, Kem. Ind. 69 (3-4) (2020) 137152, doi. https://doi.org/10.15255/KUI.2019.038.

11. A. Ibrir, Y. Kerchich, N. Hadidi, H. Merabet, M. Hentabli, Prediction of the Concentrations of $\mathrm{PM}_{1}, \mathrm{PM}_{2.5}, \mathrm{PM}_{4}$, and $\mathrm{PM}_{10}$ by Using the Hybrid Dragonfly-SVM Algorithm, Air Qual. Atmos. Heal. (2020), doi: https://doi.org/10.1007/s11869020-00936-1.

12. H. Benimam, C. S. Moussa, M. Hentabli, S. Hanini, M. Laidi, Dragonfly-Support Vector Machine for Regression Modeling of the Activity Coefficient at Infinite Dilution of Solutes in Imidazolium Ionic Liquids Using $\sigma$-Profile Descriptors, J. Chem. Eng. Data 65 (6) (2020) 3161-3172, doi: https://doi. org/10.1021/acs.jced.0c00168.

13. M. Moussaoui, M. Laidi, S Hanini, M. Hentabli, Artificial Neural Network and Support Vector Regression Applied in Quantitative Structure-Property Relationship Modelling of Solubility of Solid Solutes in Supercritical $\mathrm{CO}_{2}$, Kem. Ind. 69 (11-12) (2020) 611-630, doi: https://doi.org/10.15255/ KUI.2020.004.

14. A. Tharwat, T. Gabel, A. E. Hassanien, Classification of Toxicity Effects of Biotransformed Hepatic Drugs Using Optimized Support Vector Machine, in: A. Hassanien, K. Shaalan, T. Gaber, M. Tolba (Eds.), Proceedings of the International Conference on Advanced Intelligent Systems and Informatics 2017. AISI 2017. Advances in Intelligent Systems and Computing, vol. 639. Springer, Cham, doi: https://doi. org/10.1007/978-3-319-64861-3.

15. A. Abdallah, M. Laidi, S. Hanini, Novel Approach for Estimating Solubility of Solid Drugs in Supercritical Carbon Dioxide and Critical Properties Using Direct and Inverse Artificial Neural Network (ANN), Neural Comput. Appl. 28 (2017) 87-99, doi: https://doi.org/10.1007/s00521-015-2038-1.

16. C. Cortes, V. Vapnik, Support-Vector Networks, Mach. Learn. 20 (3) (1995) 273-297, doi: https://doi.org/10.1007/ BF00994018.

17. H. Drucker, C. J. C. Burges, L. Kaufman, A. J. Smola, V. Vapnik, Support Vector Regression Machines, in: Advances in neural information processing systems, 1997, pp. 155-161.

18. V. Vapnik, S. E. Golowich, A. J. Smola, Support Vector Method for Function Approximation, Regression Estimation and Signal Processing, In: Advances in neural information processing systems, 1997, pp. 281-287.

19. T. M. Bafithile, Z. Li, Applicability of $\varepsilon$-Support Vector Machine and Artificial Neural Network for Flood Forecasting in Humid, Semi-Humid and Semi-Arid Basins in China, Water 11 (1) (2019) 85, doi: https://doi.org/10.3390/w11010085.

20. J. Platt, Sequential Minimal Optimization: A Fast Algorithm for Training Support Vector Machines. Advances in Kernel Methods-Support Vector Learning, 1998, p. 208.

21. S. Mirjalili, Dragonfly Algorithm: A New Meta-Heuristic Optimization Technique for Solving Single-Objective, Discrete, and Multi-Objective Problems, Neural Comput. Appl. 27 (4) (2016) 1053-1073, doi: https://doi.org/10.1007/s00521015-1920-1.

22. Q.-S. Liu, T. Zheng, P. Wang, J.-P. Jiang, N. Li, Adsorption Isotherm, Kinetic and Mechanism Studies of Some Substituted Phenols on Activated Carbon Fibers, Chem. Eng. J. 157 (2-3) (2010) 348-356, doi: https://doi.org/10.1016/j. cej.2009.11.013. 
23. M. Abdelkader, M. Laidi, S. Hanini, M. Hentabli, A. Amrane, A Grey Wolf Optimizer-based Fractional Calculus in Studies on Solar Drying, Kem. Ind. 70 (1-2) (2021) 1-12, doi: https://doi.org/10.15255/KUI.2020.035.

24. Y. Mesllem, A.E.H. Abdallah, M. Laidi, S. Hanini, M. Hentabli, Artificial Neural Network Modelling of Multi-system Dynamic Adsorption of Organic Pollutants on Activated Carbon, Kem. Ind.70 (1-2) (2021) 39-47, doi: https://doi. org/10.15255/KUI.2020.011.
25. M. Laidi, A. Abdallah el Hadj, C. Si-Moussa, O. Benkortebi, M. Hentabli, S. Hanini, CMC of diverse Gemini surfactants modelling using a hybrid approach combining SVR-DA, Chem. Ind. Chem. Eng. Q. 00 (2020) 48-48, doi: https:// doi.org/10.2298/CICEQ200907048L.

26. M. Hentabli, A.-E. Belhadj, H. Benimam, F. Dahmoune, S. Keskes, Vacuum drying of the Terbinafine $\mathrm{HCl}$ powder: A kinetics study and mathematical modeling, Powder Technol. 383 (2021) 220-232, doi: https://doi.org/10.1016/j.powtec.2021.01.038.

\section{SAŽETAK \\ Modeliranje adsorpcijskog fenomena određenih fenola metodom potpornih vektora Dragonfly pomoću vlakana aktivnog ugljena \\ Mohamed Hentabli, a Abd-Elmouneïm Belhadj, and Farid Dahmoune ${ }^{\mathrm{b}, \mathrm{c}}$}

Cilj ovog istraživanja bio je izraditi matematički model zasnovan na metodi potpornih vektora (SVM) koji može predvidjeti količinu adsorbiranu u ravnoteži $\left(q_{\mathrm{e}}\right)$. Vlakna s aktivnim ugljenom (ACF) upotrijebljena su za adsorpciju određenih fenola (fenol, 2-klorofenol, 4-klorofenol, 2,4,6-triklorofenol, 4-nitrofenol i 2,4-dinitrofenol). Eksperimentalni skup podataka od 129 bodova prikupljen je iz prethodno objavljenih radova. Ulazi parametri koji su uzeti u obzir za modeliranje bili su temperatura $(T)$, koncentracija u ravnoteži $\left(C_{\mathrm{e}}\right)$ i dva deskriptora (točka vrenja $(B P)$ i gustoća (d)) za razlikovanje ispitivanih onečišćujućih tvari. Korišteni podatci prethodno su obrađeni statističkom analizom da bi se osigurala njihova primjerenost za modeliranje. Rezultati su pokazali superiornost modela DA-SVM Gaussove kernel funkcije demonstriranog njegovim koeficijentom determinacije $\left(R^{2}=0,997\right)$ i srednjom kvadratnom pogreškom (RMSE $\left.=0,027 \mathrm{mmol}^{-1}\right)$.

\section{Ključne riječi}

Adsorpcija, fenoli, metoda potpornih vektora, Dragonfly algoritam, vlakno aktivnog ugljena, količina adsorbirana u ravnoteži

a Laboratory of Biomaterials and Transport Phenomena (LBMPT), Faculty of Technology, University Yahia Fares of Médéa 26 000,

Médéa, Algeria

${ }^{b}$ Département de Biologie, Facultés des Sciences de la Nature et de la Vie et des Science de la Terre, Université de Bouira, 10000 Bouira, Algeria

c Laboratoire de Biomathématique, Biophysique, Biochimie, et Scientométrie (L3BS), faculté des Sciences de la Nature et de la Vie, Université de Bejaia, 06000 Bejaia, Algeria
Izvorni znanstveni rad Prispjelo 10. studenoga 2020. Prihvaćeno 24. veljače 2021. 